Patriotism and Nationalism in Music Education. Edited by David Hebert and Andrea KertzWelzel. Burlington, VT: Ashgate Publishing, 2012. 183 pp. ISBN 9781-1-4094-3080-3.

This timely book offers an insightful array of international perspectives on a subject that badly calls out for scrutiny. It is particularly relevant for music educators. We are currently faced with a combination of global economic distress, various military conflicts around the world, and increasing multicultural and multi-ethnic demographic trends. The connection among these factors should be obvious: under times of duress, music education faces threatened and real withdrawal of public funds in many places, and music educators seek avenues of advocacy, of which patriotic or nationalistic uses may become suddenly quite attractive or even compelling.

In the foreword to this work, Simon Keller summarizes the ongoing philosophical dispute surrounding the ideas of nationalism and patriotism. In doing so, he poses questions about the ethical limits of patriotism, and suggests that the studies in the book may inform the larger philosophical debate. In the introduction, the editors justify their use of both the words "nationalism" and "patriotism." They explain that, although both terms are often conflated with one another, they tend to be used quite differently in ordinary English (in which nationalism usually has negative connotations and patriotism positive) and philosophical discourse (in which the opposite is generally true). However, the editors point out that "nationalism" generally conjures notions of homogeneity of culture within a state or otherwise, while "patriotism" is more properly associated with loyalty to a state within circumscribed boundaries.

The research in this compilation comprises a mix of historical documentation and analyses, personal narratives, theoretical/philosophical arguments, ethnography, and several close readings of national anthems and patriotic or nationalistic songs. Apart from its foreword and conclusion, the book contains an introduction that provides the purpose, scope, and outline; a chapter providing an international overview on the subject; and nine chapters offering different perspectives on the subject from scholars representing Germany, Australia, Taiwan, the United States (one historical and one autobiographical), the Indian diaspora within South Africa, Singapore, Canada, and Finland.

Some authors provide operational definitions of the terms "nationalism" and "patriotism" within their chapters, while others do not. In most cases where these definitions are absent the connotations are made implicit through contextual cues, and these connotations do not always match up with one another. In fact, it becomes apparent that the framing of subtle contestations of the terms "nationalism" and "patriotism," as achieved through the juxtaposition of various international perspectives, is one of the most valuable aspects of the inquiry. The working definitions that an author of a given chapter chooses to favour, either 
implicitly or explicitly, seem indicative of the political realities of their respective nation-states. For example, Andrea Kertz-Welzel, providing the German perspective, explains how the ideas of nationalism and patriotism, having been so horribly abused under the Third Reich, have become negative signifiers that can now only hope to spur critical discussion about Germany's past. In contrast, Jane Southcott, representing an Australian view, hopefully refers to patriotism in school settings as the opportunity for students to be "educated in responsible citizenship."

Those authors who assume a particularly critical stance toward the book's subject are concerned about music's manipulative power. In wartime, as the editors point out in the conclusion, music's propagandistic uses in educational contexts bear even more scrutiny. For example, the notion of "blind patriotism" in the wake of the 9/11 terrorist attacks in the United States is examined in connection with the potential abuse of music education. The decision of the Music Educators National Conference (now the National Association for Music Education) to launch the National Anthem Project in 2005 is raised by the authors of chapters dealing with the United States, who are generally quite critical of the initiative.

Of particular value is the use by a number of the authors of theoretical categories or constructs of patriotism to analyze historical or qualitative data. For example, Carlos Abril explores from an historical and autobiographical perspective the American national anthem as a means of inculcating immigrants into American mainstream culture. In advocating for a critical approach to teaching about the significance of the "Star Spangled Banner," he unveils the apparent paradox of a song that should represent the ideas of participatory democracy, but instead arguably instills an unquestioning stance toward authority through its ritualistic use. This works against the more desirable outcome that Abril calls "constructive patriotism."

When authorities or others within a state encourage the adoption of what Amy Beegle describes as "dualistic patriotism" (i.e., an "us versus them" concept of political loyalty) the patriotic use of music has the potential to become dangerous by undermining notions of cultural plurality. Kertz-Welzel likens such arrangements to "Faustian pacts." The editors conclude by calling for further studies of the field. They also recommend that music educators embrace a "reconciliatory" approach in using music for nationalistic or patriotic means. This seems congruent with Wai-Chung Ho's idea of a multi-ethnic, or multicultural, sense of nationalism. Born out of the demographic reality of Taiwan's increasingly multi-ethnic society, the notion of a nationalism that embraces multiple identities is a hopeful theme that emerges from the book, and one that music educators should work toward.

\section{J. Paul Louth}

Youngstown State University 